\title{
Faculty Development: The Why and the How of It
}

\section{Joseph B. Cuseo}

Marymount College

A recent report by the Carnegie Foundation based on three years of on-site visits and extensive survey findings drew the following conclusion:

The undergraduate college, which depends so much on vitality in the classroom, must be served by faculty members who can be renewed throughout their careers. And yet, we found that such an obvious and important practice as setting aside a portion of the budget for faculty development is rare. We strongly recommend that every college commit itself to the professional growth of all faculty. (Boyer, 1987, p. 134)

This article responds to this disturbing finding and was written with two objectives in mind: (a) To document why higher education would be more effective if it made a strong commitment to faculty development; and (b) To suggest how a faculty development program might be conducted in order to be as effective as possible.

\section{The Need for an Effective Faculty Development Program}

A compelling case can be made for the importance and urgency of faculty development programs when one considers the following issues confronting higher education today.

\section{Redressing Low Faculty Morale}

A recent Carnegie Foundation survey of 5,000 faculty members in more than 300 institutions revealed that 40 percent of them saw morale in their department as "worse than it was five years ago"; 40 percent reported 
experiencing "decreasing interest in their work"; and more than 50 percent reported that they were considering "leaving academe" (Jacobson, 1985). Similar results were reported by a team of six researchers who conducted intensive interviews with more than 500 faculty and administrators at 38 diverse campuses:

All in all, faculty mood was glum. Making allowances for the varied circuinstances of the thirty-eight campuses in our sample, we found that faculty members tended to be apprehensive and discontent. The common view was that faculty life had once upon a time been better and that conditions could very well get worse, maybe a lot worse, in the foreseeable future. Our overall sense was that faculty were frustrated and dispirited. (Bowen \& Schuster, 1986, p. 146)

Such findings suggest that many institutions of higher education need some mechanism for promoting faculty members' career adjustment and growth. An effective faculty development program could serve this needed function.

\section{Preparing the Increasing Number of Newly Hired Faculty for Their Role as College Instructors}

It has been estimated that by the year 2000 , half a million new faculty members will be needed in American higher education to replace large numbers of retiring faculty. Bowen and Schuster point out that

Over the next twenty-five years, our colleges and universities will probably require nearly as many faculty appointments (full-time equivalent) as there are members in the professoriate today .... Moreover, sad to say, the youthful candidates for faculty positions in the near future will include the generation that was characterized by declining test scores, inadequate high school preparation in the basic subjects, and college education with underemphasis on general education. (1986, pp. 165168)

Couple these projections with the fact that the graduate training of college professors has been found to be generally ineffective in preparing them for their role as teachers (Association of American Colleges, 1985; Newman Unit's Report on Graduate Education, 1973), and we are left with the prospect that American higher education will soon experience a surge of new, inexperienced, and underprepared instructors. A faculty development program with an effective instructional improvement and 
growth plan could be an ideal mechanism for addressing the teaching needs of new faculty.

\section{Addressing the Developmental Needs and Interests of Senior Faculty}

There is evidence indicating that senior faculty, as they look to the end of their professional careers, tend to shift their priorities and interests toward teaching (Blackburn et al., 1986; Rice, 1983). A faculty development program could address the developmental needs of senior faculty by orchestrating activities relevant to the issue of effective college teaching. Such activities might, for example, address the needs of "new" types of students, such as academically "underprepared" students and "nontraditional" learners.

\section{Addressing Changing Student Needs}

Data collected annually by the Cooperative Institutional Research Program (CIRP) between 1966 and 1984 have revealed a decline in student scores on standardized tests and reduced student interest in intellectual issues and social problems (Astin, 1966-1984). The perceptions of college faculty agree with these reports; as evidenced by the following survey data collected in 1984 by the Carnegie Foundation: 54 percent of faculty reported that "the academic ability of the undergraduates at my institution is "fair to poor"; 57 percent reported that present academic standards for undergraduate admission should be "higher"; and 66 percent reported that their institution "spends too much time and money teaching students what they should have learned in high school." All these percentages were higher than what faculty reported in 1975 (Carnegie Foundation, 1975 and 1984). More recently, Clark (1987) conducted intensive, nationwide interviews with 170 faculty members at 16 different institutions, ranging from community colleges to research universities, and found a decline in faculty morale due, in large measure, to dissatisfaction with the academic preparation of contemporary students. Furthermore, there is evidence that the underprepared student will be part of higher education for years to come (Hodgkinson, 1983).

All these findings suggest that college instructors might be well served by faculty development efforts designed to help them cope with this "new breed" of student and to encourage them to perceive the academically underprepared student as an instructional challenge rather than as a morale-sapping liability. 
In addition to meeting the challenge of effectively teaching underprepared students, college faculty are now encountering a second type of new student: the "nontraditional" learner or returning "adult" student. These adult learners represent the fastest growing segment of higher education: "The majority of students enrolled in the 1990's will be parttime adult learners, not the traditional 18-year-old, full-time student" (Spelle, 1987, p. 3). These adult students may require different instructional approaches than those historically used to teach traditionally aged college students (Knowles, 1984; Wlodkowski, 1985), and faculty development may be a viable method for preparing college instructors to effectively meet the unique needs of these nontraditional learners.

\section{Improving the Overall Quality of Undergraduate Education}

Within the last few years, several national reports on the condition of American higher education have sharply criticized the quality of undergraduate instruction (e.g., reports issued by the Association for American Colleges, 1985; Carnegie Foundation, 1984-85; National Endowment for the Humanities, 1984; National Institute for Education, 1984). A common theme in these reports is that the quality of undergraduate education is suffering for one or more of the following reasons:

1. Lack of adequate instructional preparation of college faculty prior to their entering the professoriate: "During the long years of work toward the doctoral degree, the candidate is rarely, if ever, introduced to any of the ingredients that make up the art, the science, and the special responsibilities of teaching. Yet the major career option for most holders of the Ph.D. degree is full-time teaching in a college or university" (Association of American Colleges, 1985, p. 13). This conclusion is strikingly reminiscent of one reached by a study group on higher education some ten years earlier: "It is probably not an exaggeration to say that the present disjunction between the emphasis in graduate training and the work done by most college teachers is a formula for occupational schizophrenia" (Group for Human Development in Higher Education, 1974, p. 30).

2. Overly narrow specialization in graduate school, perpetuated by sharp disciplinary divisions, disciplinary isolation, and lack of interdisciplinary dialogue among the professoriate: "The disciplines have fragmented themselves into smaller and smaller pieces, and under- 
graduates find it difficult to see patterns in their courses and to relate what they learn to life" (Boyer, 1987, p. 3).

3. Lack of open discussion among faculty about the teaching process and how to improve its effectiveness. This criticism reinforces the findings of an extensive survey of 1,680 faculty at 14 institutions conducted by Gaff, in which he found that 42 percent of those surveyed said that never during their entire teaching career had anyone "talked with [them] in detail about their teaching." Only 25 percent said that such discussions took place more than once. One faculty respondent wryly noted that "teaching has replaced sex as a taboo topic" (1978, p. 45). More recently, Bok concluded: "Professors are among the most independent of all professionals and guard their autonomy closely .... . Such attitudes help us to understand why it would not be feasible to prescribe collective goals or teaching methods. They do not explain why there is so little discussion of ways to improve the educational process" $(1986$, p. 64). Faculty development efforts aimed at promoting interdisciplinary dialogue and open discussion of teaching/learning issues could be an effective mechanism for redressing these criticisms of the American professoriate and, in so doing, enhancing the overall quality of undergraduate education.

\section{Increasing Empirical Evidence That Faculty Development Activities Produce Positive Results}

Evidence suggests that faculty development programs are effective as measured by faculty satisfaction (e.g., Hoyt \& Howard, 1978). Furthermore, a growing body of recent, well-conducted research provides empirical documentation of the value of faculty development programs in promoting college teaching effectiveness in particular. For example:

1. Cohen conducted a meta-analysis of a large number of specific strategies designed to promote instructional improvement and concluded, "When teachers are left to their own resources, [student] ratings provided little help. Augmented feedback, or, more specifically, expert consultation seems to be the key element for making student rating data usable for improvement purposes" (1981, p. 33).

2. Menges and Brinko (1986) conducted a more recent meta-analysis of a large number of instructional improvement efforts and also found that faculty members who received assistance from an instructional 
development consultant were rated higher in teaching effectiveness by students than 86 percent of faculty who did not receive any consultation.

3. Stevens and Aleamoni (1985) performed a longitudinal study following up on faculty who received assistance from an instructional improvement professional and found that the positive results of such assistance persisted for up to ten years.

4. Levinson-Rose and Menges (1981) reviewed a large number of studies on the effectiveness of instructional improvement workshops and found that more than 80 percent were effective as evidenced by improved student ratings of instruction, improved ratings by trained in-class observers, and improved student learning (i.e., improved student performance on examinations).

5. Eble and McKeachie, following their comprehensive review of faculty development programs, concluded:

When effectiveness of faculty development programs is measured by participation, instructional development activities (e.g., workshops, seminars) were most effective... Our analysis suggests that even though grants for individual scholarly programs are valued ... faculty members working together to achieve common objectives may be more cost-effective for the institution in terms of their impact on student learning. (1985, p. 205)

6. Lacey published a more recent review of faculty development programs and concluded that seminars and workshops that are both popular and effective are those that

address practical needs and can result in tangible changes in the way faculty teach ... Some of the most valuable reported outcomes of successful workshops or seminars have to do with increased collegiality and better communication among faculty ... and better communication comes as a by-product of working on matters of importance to us as teachers. (1988, pp. 64-65)

If we couple all these research findings pointing to the effectiveness of consultation and workshops for improving teaching effectiveness with all the national reports suggesting that the quality of undergraduate education is in dire need of improvement, a strong case can be made for the potential value of faculty development programs designed to promote instructional improvement and growth. 


\section{Goals and Objectives of an Effective Faculty Development Program}

A comprehensive faculty development program should effectively address each of the following three general objectives:

\section{Promoting the Professional Development of Faculty}

It seems reasonable to contend that the primary goal of an effective faculty development program is to assist faculty to improve their performance of their professional responsibilities. This general goal is best achieved by systematically identifying the particular performance expectations (both tacit and explicit) of faculty at a given institution. More specifically, what job-related activities are faculty expected to perform in order to fulfill the college's mission and to be retained and promoted? Once this detailed "job analysis" is completed, the next step is to identify the relative importance or weight given to each of these various responsibilities (i.e., how are these specific job expectations prioritized by the institution in terms of mission fulfillment and personnel decisions?).

An effective faculty development program should then systematically address each of these key areas of professional responsibility in a way that reflects their relative importance for the institution's mission and its faculty evaluation system. For example, if teaching and advising receive higher institutional priority than research and community service, then faculty development efforts should be more heavily directed toward assisting faculty to achieve excellence in the areas of teaching and student advising.

An effective faculty development program also enables faculty to integrate their various professional responsibilities in such a way that they complement, rather than contradict, each other. Recent research findings suggest that such integration of professional responsibilities seems to be especially needed in order to reconcile the dual roles of teaching and research. Clark, after conducting intensive interviews with $\mathbf{1 7 0}$ faculty members at 16 different institutions, concluded: "Despite protestations that teaching is research and research is teaching... professors themselves consistently sense that one activity draws time and energy from the other. They talk about this tension and wonder about its resolution" (1987, p. 99). Bowen and Schuster, who conducted intensive interviews with more than 500 faculty and administrators at 38 campuses, found 
considerable tension among various segments of the faculty, a tension attributable in some measure to the heavy emphasis on research ... [which was] also evidenced at a number of institutions where in the past scholarly productivity was rare and effective teaching was the paramount criterion by which faculty were hired and promoted .... The junior faculty at many of the campuses we visited had become, in a sense, "privatized"; that is, the overwhelming pressure to produce and publish had isolated them. (1986, p. 147)

Consistent with these findings is Pat Cross's observation that college faculty are now experiencing a growing discrepancy between intrinsic and extrinsic rewards:

Most college teachers claim that they are more interested in teaching than in research (Carnegie Survey, 1985), and that they teach primarily for intrinsic satisfaction (McKeachie et al., 1986). However, in the light of the recent surge toward rewards for research (Schuster \& Bowen, 1985), some teachers feel forced to give up the intrinsic satisfactions of teaching for research. Poor morale is the result when the gap between intrinsic and extrinsic rewards becomes excessive. $(1988$, p. 7)

A faculty development program could explore ways of encouraging faculty to engage in research and scholarship that are congruent with their teaching responsibilities, instead of engaging in research pursuits that take time away from their commitment to instructional excellence. For instance, faculty could be encouraged to engage in research activities that have practical implications for enhancing the quality of their own instruction and that contribute to the scholarly literature on teaching and learning. The "classroom research" suggested by Cross (1987) may be offered as one effective way to achieve congruence between instructional and research responsibilities and to reduce the gap between intrinsic and extrinsic rewards.

\section{Promoting the Personal Development of Faculty}

A second, related goal of an effective faculty development program would be to enhance the quality of faculty members' personal lives in ways that extend beyond merely improving their job performance. For instance, a natural extension of faculty development efforts should be heightened career satisfaction and a reduction in job-related stress, which, in turn, should have beneficial impact on faculty life outside academe. The increased interaction with other faculty that emerges from faculty development efforts (e.g., workshops, seminars) may increase the likelihood that 
mentoring and friendships will extend beyond the institution. Such efforts would be especially relevant for contemporary institutions of higher learning because "the increasing size and complexity of many of our campuses erodes the capacity for collegial relations" (Bowen \& Schuster, p. 145).

In addition to these corollary personal benefits associated with efforts to promote professional development, more direct measures may be taken to address the goal of promoting faculty members' personal development by offering services explicitly aimed at enhancing the quality of their personal lives (e.g., stress management workshops, exercise groups, nutrition seminars). Such personal development programs have already been successfully implemented in corporate organizations under the rubric of "quality of work life" (QWL) programs (Schultz \& Schultz, 1986). The need for such personal development efforts in higher educational organizations is highlighted by the research of Near and Sorcinelli (1986), who found that faculty work satisfaction was significantly related to general life satisfaction and that the degree of this relationship was higher for faculty than it was for the general work population.

\section{Promoting the Development of the Institution}

A third major goal of an effective faculty development program would be to promote institutional/organizational quality. All constituencies in the college community should benefit from a high-quality faculty development program. For example, students should profit from more effective teaching and academic advising, interdepartmental dialogue and collegiality should be improved by faculty development efforts designed to bring together faculty from different disciplines to discuss common concerns (e.g., the teaching/learning process), and team-building between faculty and administration should be promoted (e.g., by faculty development efforts to assist deans and chairpersons in the evaluation and improvement of college teaching or in the development of faculty "growth" plans; by faculty development efforts to increase faculty retention, thus reducing turnover and the need for expensive, time-consuming searches).

If this objective of faculty development is realized, then an organizational climate would be created in which faculty and administration perceive their own professional goals as congruent with the institution's goals and mission:

If isolated from or even working against other vital issues confronting an institution, it [faculty development] will have little or no impact. Yet if 
faculty development is systematically and patiently implemented as part of a comprehensive program of institutional renewal, it can have profound and lasting impact on the lives of faculty, their administrators, and their students. (Bergquist \& Phillips, 1975, pp. 265-266)

In a research project that sought to assess the impact of facuity development grants to 20 leading liberal arts colleges nation-wide, it was found that "faculty development activities achieve their greatest success when they are related, somehow, to institutional mission, and when they palpably influence the achievement of that mission" (Siegel, 1980, p. 135).

\section{Effective Program Activities}

Decisions about what activities are effective for promoting faculty development should be guided by two key criteria: (a) Would the planned activity relate meaningfully to the major goals/objectives of the faculty development program, that is, would it be effective for promoting faculty members' professional development, personal development, or the institution's development? and (b) Has the activity been planned with at least some faculty input or involvement?

Probably the first step in planning faculty development activities should be a carefully conducted "needs assessment" (e.g., topics/issues faculty would like discussed, preferred activity formats and times, and so on). Subsequent faculty development activities should then be planned with these expressed needs in mind. Establishment of an ongoing faculty development committee composed of faculty representing a variety of disciplines and levels of experience would be an effective way to keep faculty development efforts continually in line with faculty needs and interests. The faculty development committee meetings could be widely announced and open to the faculty at large, so that an even greater degree of input and involvement could be achieved. Such procedures would serve to give faculty some sense of ownership or control of the program and give them a feeling that the program is something being done for them rather than to them; this sense of ownership, in turn, should increase their motivation to participate in faculty development activities.

Given that the planned faculty development activity meets the two criteria of relating meaningfully to the program's objectives and being responsive to faculty needs, the following range of activities are recommended for consideration: 


\section{Monthly Newsletter}

Such a newsletter would contain practical, professionally relevant news that faculty could use immediately (e.g., information on recent trends and innovations relating to faculty development in higher education; research-based "tips" on teaching and advising; publication and grant-writing strategies). The newsletter would function as a "feeder" of timely information to faculty who often lack the time to peruse the professional literature. Appended to the newsletter could be a response form through which individual faculty members could request additional information, express an opinion or reaction, or provide practical suggestions of their own (e.g., the newsletter could contain a "what works for me" section to accommodate faculty members' practical recommendations).

\section{Faculty Development Materials Center}

Housed in a section of the library or the faculty lounge, such a center would be stocked with continually updated literature on issues relating to faculty growth and development and would include audio-visual resources (e.g., videos of successful teachers practicing their craft or illustrating specific instructional techniques; some of these illustrative cases could be drawn from outstanding campus faculty).

\section{Seminars and Workshops}

These could be offered periodically on campus during the academic year or as part of a pre-semester, off-campus retreat designed to build enthusiasm for the upcoming academic year. Issues addressed by such workshops should be practical, reflect faculty needs and input, and be consistent with the objectives of the faculty development program. Faculty should be canvassed for dates and times when they would be able to attend. If possible, workshops should be offered at more than one time in order to accommodate the schedules of as many faculty as possible. Invariably, there will be some faculty members who cannot attend at any of the scheduled times. I would recommend that "minutes" of the workshop and seminar be recorded and sent to all faculty who did not attend. My experience has been that faculty are usually appreciative of such summarizing handouts. In fact, I would recommend sending the seminar summaries to the entire faculty, even to those who have expressed no interest in attending. I have discovered that, in some cases, such "intrusively" provided workshop summaries have whetted the interest of 
previously non-participating faculty and were instrumental in motivating them to attend subsequent faculty development activities.

Research has indicated that workshop experiences in which faculty come together to address practical needs are most effective for "promoting communication and collegiality among faculty" (Lacey, 1988, pp. 64-65) and are most effective for the institution "in terms of their impact on student learning" (Eble \& McKeachie, 1985, p. 205).

It is further recommended that workshop follow-up activities be planned to provide some sense of continuity (e.g., a follow-up questionnaire issued several weeks after the workshop to see if attendees have put any workshop ideas into practice, or a "user's reunion" of those faculty who have attempted to implement workshop ideas). Research suggests that such follow-up activities play an important role in determining whether the workshop has any significant long-term benefits (Joyce \& Showers, 1983). As Bergquist and Phillips put it, "A workshop should be used primarily to whet the appetite of a faculty member. More intensive one-on-one consultation usually is needed to effect signifcant change and improvement in instructional performance" (1981, p. 156).

\section{Faculty Interviews}

One-to-one contact with individual faculty via personal interviews is an effective means for faculty developers to know their faculty (e.g., their educational backgrounds, their professional and avocational interests). Most faculty welcome someone's taking a personal interest in them, especially first-year faculty who may still feel they are trying to earn their welcome or prove their worth. The faculty developer could also use information obtained through interviews to help build networks among faculty who happen to share similar professional or personal interests; for example, a faculty directory or "who's who" could be compiled and circulated to foster such networking. Furthermore, interview questions pertaining to faculty members' teaching philosophies, goals, and instructional methods might serve to raise their consciousness about the teaching/learning process and stimulate them to talk to each other about these issues on their own:

No faculty development program can take place unless faculty members themselves want it. Hence, the first step is to create conditions that will stimulate faculty members to think about their institutional situations and their own development. Perhaps the best way of accomplishing this improvement in faculty ethos is to initiate an extensive plan for comprehensive interviews of large segments of the faculty .... It has been 
our experience that faculty members almost universally enjoy such interviews. The questions, once asked, open doors that have too often been kept tightly closed .... In many instances, faculty members will report that they have never before considered the subjects discussed. If significant proportions - "critical masses" - of the faculty members in a department, or a school or a college participate in an extensive interview program, they are likely to discuss the interviews with each other, creating an atmosphere in which the issues of the interviews become subjects for general conversation. Widespread interest is thereby generated. (Freedman et al., 1979, pp. 155-156)

\section{Teaching Consultation}

The faculty developer could serve as a consultant to individual faculty members seeking to improve their teaching. Such a service would be strictly voluntary and confidential. Rather than posing as an expert authority whose charge is to rescue a floundering or incompetent instructor, the faculty developer should approach the consultation task as a learned faculty peer or collegial coach who is still in the process of trying to understand and improve the teaching/learning process. The faculty developer must tactfully approach consultation as an effort to stimulate professional growth among an already competent faculty, rather than providing a remedial service for teachers experiencing instructional difficulties:

At times the phrase "faculty development" has a scary ring. Too often "develop" is used in the active sense: faculty are wanting, and something will be done to perfect them, evolve them or promote their growth. The spirit resembles that of Western colonialism. Let us Christianize the heathen or civilize the benighted. Faculty members with a modicum of self-respect and dignity resent being treated this way. (Freedman et al., 1979, p. x)

Sensitivity must be shown toward the instructor who may be dealing with the shock, discouragement, and/or anger of receiving less-than-satisfactory student evaluations. Recognizing the instructor's strengths (and explaining specifically why they are strong points) may be one way to reassure the instructor of his or her general competence and restore professional self-esteem. Once this empathy and support have been provided by the faculty developer, the instructor is less likely to feel threatened by suggestions for improvement and will be more likely to act upon them. 
To obtain an accurate and complete picture of the instructor's strengths and areas that need improvement, the faculty developer should utilize multiple informational sources, including:

1. A personal interview with the faculty member to determine and clarify her instructional objectives, to assess how instructional methods relate to these stated objectives, and to identify how her methods of evaluating students (assignments, tests, and so on) relate to her instructional objectives and methods.

2. In-class observation of the instructor's teaching, guided by some systematic model or conceptual framework that serves to focus the consultant's attention on those instructional behaviors most relevant to effective teaching and learning.

3. Videotapes of the instructor's teaching that could be used to analyze and identify specific teaching behaviors (e.g., via stop-action, replays) and to provide immediate feedback (e.g., the instructor observes a particular instance of his own behavior on videotape and immediately receives feedback from the consultant on its effectiveness).

4. A review of student evaluations with the instructor to gain insight into student perceptions of the instructor's strengths and weaknesses. Further information could be obtained by comparing and contrasting student perceptions with the instructor's self-perceptions. Items on the evaluation form showing the greatest discrepancy between student and teacher perceptions would be useful in identifying target areas for consultation.

To maximize the instructor's opportunity to make improvements while there is still time to prevent a packet of poor student course evaluations from arriving at the academic dean's office and becoming part of the instructor's personnel file, the course evaluation forms could be administered at midterm for instructional improvement purposes. These evaluations would be reviewed by the consulting faculty developer, and the instructor could then attempt to implement recommended instructional improvement strategies and redress student complaints before the final, end-of-course evaluations are given. Another advantage of this procedure is that it allows comparisons between student ratings prior to consultation (at midterms) with ratings received after consultation with the faculty developer (end-of-course). Significant pre- to post-consultation improvement in student evaluations could serve as evidence for the effectiveness of the consultation process. 
The likelihood that consultation will improve teaching effectiveness will depend heavily on the nature or substance of the feedback provided. Recommendations for instructional improvement that represent specific, behavioral, concrete, action-oriented strategies are most likely to result in implementation and improvement. Empirical support for this contention is provided by Wilson, who conducted research on the effects of teaching consultation for improving instructors' course evaluations and discovered that "items on which the greatest number of faculty showed statistically important change were those for which the suggestions were most concrete, specific and behavioral" (1986, p. 209).

A further step to ensure the consultation's effectiveness is systematic follow-up by the faculty developer. I would recommend that a personal letter be sent to the instructor as soon as possible after the consultation process is completed. This letter would serve to synthesize and reinforce the verbal recommendations made during consultation to encourage the instructor to seek out future collegial contact with the faculty developer. This formal correspondence could be followed by an informal phone call to the instructor at some later date-just to "touch base" and check on how things are going.

If the faculty developer can establish an effective teaching consultation program on campus, it may generate benefits beyond helping individual faculty on a case-by-case basis. A successful teaching consultation program could also serve to stimulate faculty dialogue on teaching in general, perhaps altering institutional "culture" in such a way that open, mutually supportive discussion of teaching issues and practices becomes the norm rather than the exception. Furthermore, individual faculty who have been successfully "coached" in the consultation program may themselves become effective "coaches" for their teaching peers-perhaps resulting in a "coaching network" that would have a more pervasive influence on teaching effectiveness than the faculty developer alone could possibly achieve.

\section{Guest Speakers}

Outside speakers with special expertise in issues pertinent to faculty development may provide a fresh, extra-institutional perspective. It is my experience, however, that great care must be taken in speaker selection; nationally prominent experts who have built their reputation through prolific publication records do not always make the best speakers and workshop leaders. A little background research on the quality of a potential speaker's previous workshop presentations may go a long way in 
preventing a workshop that "bombs" (as well as a severe blow to the overall credibility of the faculty development program). Contacting other faculty developers for recommended speakers may be one way to conduct this background check. Perhaps an "effective speakers network" could be developed with neighboring colleges to identify a pool of high-quality presenters and to minimize travel expenses incurred by the colleges. For example, nearby colleges could share the travel expenses of a guest speaker by arranging for him or her to make one trip to deliver presentations at two or more colleges in the same geographical area.

It has also been my experience that some outside speakers tend to give "canned" presentations, focusing on their own present interests rather than your faculty's needs and interests. To guard against this possibility, I would recommend that guest speakers be given a very clear sense of the issues you would like addressed (i.e., verbally agreed upon, first by phone, then further reinforced and delineated via written correspondence - "get it in writing"). Canvassing the faculty for questions they would like the speaker to address would be one way to increase the speaker's responsiveness to faculty interests and enhance the likelihood that faculty will anticipate a relevant presentation (thereby enhancing the likelihood that they will attend).

Lastly, it is inevitable that a significant percentage of faculty will be unable to attend the guest speaker's seminar at the scheduled date and time. To accommodate those faculty unable to attend, the session should be videotaped and made available for faculty viewing. These videotapes, along with any workshop handouts, could become permanent additions to the faculty development materials center on campus.

\section{"Focus-on-Faculty" Programs}

In addition to outside experts and consultants, faculty on campus represent a valuable information resource on topics and issues pertinent to faculty development. For instance, faculty members in communication studies could provide valuable workshops on effective speaking skills that would be relevant for improving lecture presentations; faculty in computer science and communications media may have expertise in applications of these technologies to instruction and research; faculty with scholarly interests in cross-cultural issues and multicultural education could provide valuable in-services on how to communicate better with international and minority students. In addition, forums could be provided in which faculty can share their current scholarly interests and 
accomplishments with other faculty (e.g., at a luncheon, wine and cheese reception, or pot-luck dinner hosted at a faculty member's home).

Such faculty-focused and faculty-conducted activities could serve the dual purpose of increasing interdepartmental dialogue and collegiality and increasing faculty's active involvement in the faculty development program - as respected expert contributors.

\section{Orientation Program for New Faculty}

Research has consistently impugned graduate schools for their inadequacy in preparing students for their role as college professors, particularly in the areas of teaching and student advising (Association of American Colleges, 1985; Newman Unit's Report on Graduate Education, 1973). Research also indicates that first-year faculty receive substantially lower instructional ratings than more experienced faculty (Centra \& Cruch, 1976), with many receiving "less than satisfactory" student evaluations (Turner \& Boice, 1987). At the same time, many first-year faculty report being "the busiest they had ever been in their lives," largely due to teaching-related activities such as course preparation. They also report experiencing "significant job-related stress" (Turner \& Boice, 1987).

Sorcinelli found similar results with new faculty: "About half the sample reported stresses in teaching. The major culprit was the time it took to develop courses ... teach, evaluate, and advise students" (1988, p. 126).

All these data suggest that first-year faculty members need assistance in making the transition into the professoriate and that they probably would be very receptive to such assistance. Faculty development could provide this assistance in the form of a comprehensive faculty orientation program for new professors. Such an orientation should include the usual "nuts and bolts" survival information (e.g., review of institutional expectations of faculty; information on where to park, get chalk, make photocopies, and how to prepare a file for promotion-and tenure review), but should also provide comprehensive coverage of effective teaching and advising practices (c.g., course planning and design, instructional delivery and discussion techniques, testing and grading, student development, and student advising). It is noteworthy that in a major study of faculty development programs at 20 leading liberal arts colleges across the nation, it was found that there was only one actual attempt to deal with the issue of student advising, which is "unavoidably a crucial aspect of a faculty member's role" (Siegel, 1980, p. 135). 
To do service to the full range of adjustment needs of new faculty, I would argue that this orientation program should be extended into a full-semester seminar (e.g., one three-hour weekly session for 15 weeks). This orientation seminar could be offered to new faculty in lieu of some other professional responsibility that normally would be required during their first semester on campus (e.g., no committee assignments for firstsemester faculty, or a one-course reduction in teaching load).

A further advantage of an ongoing orientation seminar for new faculty would be that collegial "bonding" may occur among faculty peers because (a) they experience regular contact with fellow first-year instructors, and (b) they are provided with a regular forum for timely discussion and resolution of adjustment issues arising during the often stressful first semester of college teaching. Such a comprehensive orientation program could serve as an effective pro-active measure to "short-circuit" some of the professional difficulties and stresses typically experienced by first-year faculty.

\section{Faculty Mentoring Program}

Research on career development has suggested that having a mentor may play a key role in an individual's professional success (Levinson, 1978), but, unfortunately, this mentoring process does not seem to occur naturally or spontaneously among faculty in higher education (Turner \& Boice, 1987). Research has also revealed that new faculty anticipate frequent informal interactions with senior colleagues and expect experienced faculty to be a source of companionship and constructive advice. Most new faculty, however, report low levels of collegiality with senior faculty and further report that frustration of these collegial expectations is a major source of professional dissatisfaction for them (Fink, 1984; Sorcinelli, 1988; Turner \& Boice, 1987).

Reporting on the effectiveness of a faculty development program he directed, Hipps concluded that:

However fervently some faculty may wish to preserve the tradition of casual, unstructured relationships between older and younger faculty members, it seems clear that some younger faculty with the most pressing needs will often not directly seek the help of an experienced colleague, especially one in another department. Likewise, many older faculty who have a great many insights to offer may be reluctant to meddle or to appear immodest in an attempt to assist their younger co-workers, especially those in other disciplines. In sum, younger and older faculty have much to offer each other, but a structured program 
may be necessary to bring them together for mutual benefit. (1980, $p$.

48)

These results suggest that a formal mentoring program, one in which the new faculty member is paired with a knowledgeable and sensitive senior professor, may be an effective procedure for promoting collegiality and the professional growth of both new and senior faculty. Other research reported by Busch (1985) and Gerstein (1985) indicates that the mentor reaps significant professional and personal benefits from the mentoring process as well.

\section{Program Evaluation}

Effective evaluation of a faculty development program should involve assessment of each of its individual activities as well as the program as a whole. Evaluation should include affective measures (e.g., structured interviews assessing how faculty feel about the program and its activities; Likert-scale ratings of faculty satisfaction/dissatisfaction with the program, including ample opportunity for written comments) and behavioral measures (e.g., number and variety of faculty actually attending program activities; number of faculty making follow-up inquiries/comments in response to articles in the program's newsletter; number of faculty actually implementing strategies/methods suggested in the program's newsletter and workshops; number and variety of faculty using the program's teaching-consultation service; number of faculty reporting regular contact with other faculty members resulting from the program's activities; number of faculty attaining promotion and tenure before and after implementation of the faculty development program).

In addition to formal quantitative methods of evaluation, the faculty developer can also gain useful feedback on program effectiveness through extensive dialogue with his or her faculty colleagues. A developer who openly seeks honest feedback and responds to it in a non-defensive manner will gain access to a subtle yet rich source of evaluative information that would be missed if he or she relied exclusively on formal, structured assessment measures: "Questionnaires and environmental scales rarely tap the rich insights, telling biases, and deep-felt convictions that often surface during an intensive interview" (Bergquist \& Phillips, 1981, pp. 316-317). 


\section{Role of the Program Director}

In my estimation, an effective faculty developer should be able to successfully fulfill each of the following roles:

1. The director should be a role model for faculty in terms of fulfilling his professional responsibilities. For example, the director should be highly regarded for teaching ability, scholarship, and service to students, the institution, and the community. A director who has a proven "track record," who is respected for demonstrating a commitment to excellence in all facets of professional life, will be perceived as credible and will effectively stimulate the professional growth of others by his example.

2. The director should be a resource for faculty needs. This role requires that the director be well informed and equipped with accurate information on issues related to professional development (e.g., she should have a thorough knowledge of the literature on effective collegeteaching practices), personal development (e.g., she should be conversant with practices and resources for promoting personal adjustment and growth), and institutional organizational development (e.g., she should be knowledgeable about organizational research and effectiveness so that the goals of the faculty development program can be integrated with the broader goal of promoting institutional quality).

3. The director should be an effective liaison between individual faculty members and other key members of the academic community: faculty peers, administrators, and students. This role requires that the director have good interpersonal skills. He should have the ability to bring faculty together and promote networking among faculty from different disciplines. For instance, a faculty developer who is personable, and who takes the time to know faculty well (e.g., knowing their scholarly and avocational interests), is in a good position to identify interests shared among faculty from otherwise disparate departments, thereby facilitating interdisciplinary dialogue and collegiality.

A faculty developer with good interpersonal skills should also serve as an effective liaison or "team builder" between faculty and administration by keeping administrators abreast of faculty perspectives and needs, and by mediating collegial dialogue between faculty and administration on issues that the faculty developer's needs-assessment research indicates are areas of concern. 
Finally, the faculty developer should be able to serve as an effective liaison between faculty and students. Close communication with students and the department of student affairs would enable the faculty developer to better assist faculty in professional activities that have an important impact on students. For example, if the developer learns that students are expressing dissatisfaction with the quality of faculty advising or faculty availability outside class, then she has obtained information that provides important direction for immediate faculty development efforts designed to address these specific concerns.

4. The director should be an effective advisor and counselor. Some of the faculty developer's responsibilities may involve highly sensitive issues (e.g., helping an instructor deal with negative student evaluations; helping faculty meet their department chair's demands for increased scholarly activities). To function effectively in this role, the faculty developer has to be a good listener, someone in whom faculty can confide, and someone who can provide constructive criticism in a way that does not threaten a faculty member's professional or personal self-esteem. The faculty developer who is both empathic and tactful is one who will be best able to garner the trust, respect, and cooperation of the faculty she serves.

\section{References}

Association of American Colleges. (1985). Integrity in the college curriculum: A report to the academic community. Washington, DC. Reprinted in the Chronicle of Higher Education, February 15, 1985.

Astin, A.W. (1966-1984). The American freshman: National norms. Los Angeles, CA: Higher Education Research Institute.

Bergquist, W., \& Phillips, S. (1975). A handbook for faculty development, volume I. Washington, DC: Council for the Advancement of Small Colleges.

Bergquist, W., \& Phillips, S. (1981). A handbook for faculty development, volume III. Washington, DC: Council of Independent Colleges.

Blackburn, R.T., et al. (1986). Faculy as a key resource: $A$ review of the research literature. Ann Arbor, MI: National Center for Research in Postsecondary Teaching and Learning.

Bok, E.L. (1986). Higher learning. Cambridge, MA.: Harvard University Press.

Bowen, H., \& Schuster, J. (1986). American professors: A national resource imperilled. Oxford, England: Oxford University Press. 
Boyer, E.L. (1987). College: The undergraduate experience in America. New York: Harper \& Row.

Busch, J.W. (1985). Mentoring in graduate schools of education: Mentors' perceptions. American Educational Research Journal, 22(2), 257-265.

Carnegie Foundation for the Advancement of Teaching, National Surveys of Faculty, 1975 and 1984. Reprinted in E.L. Boyer (1987), College: The undergraduate experience in America. New York: Harper \& Row.

Carnegie Survey. (1985). Reprinted in the Chronicle of Higher Education, December 18, 1985.

Centra, J.A., \& Cruch, F.R. (1976). The relationship between student, teachers, and course characteristics and student ratings of teacher effectiveness. Project Report 76-1. Princeton, NJ: Educational Testing Service.

Clark, B.R. (1987). The academic life: Small worlds, different worlds. Lawrenceville, NJ: Princeton University Press.

Cohen, P.A. (1981). Student rating of instruction and student achievement: A meta-analysis of multisection validity studies. Review of Educational Research, 51, 281-309.

Cross, K.P. (1987). The need for classroom research. In J. Kurfiss, L. Hilsen, S. Kahn, M.D. Sorcinelli, and R.G. Tiberius (Eds.), To improve the academy, 6, 3-17.

Cross, K.P. (1988). In search of zippers. AAHE Bulletin, 40(10), 3-7.

Eble, K.E., \& McKeachie, W. (1985). Improving undergraduate education through faculty development. San Francisco, CA: Jossey-Bass.

Fink, L.D. (1984). First year on the faculty: Being there. Joumal of Geography in Higher Education, 8, 11-25.

Freedman, M., et al. (1979). Academic culture and faculty development. Berkeley, CA: Montaigne Press.

Gaff, J. (1978). Overcoming faculty resistance. In J. Gaff (Ed.), Institutional renewal through the improvement of teaching. New Directions for Higher Education, 24 (pp. 43-56). San Francisco, CA: Jossey-Bass.

Gerstein, M. (1985). Mentoring: An age-old practice in a knowledge-based society. Journal of Counseling and Development, 64, 156-157.

Group for Human Development in Higher Education. (1974). Faculty development in a time of retrenchment. New York: Change Publications.

Hipps, G.M. (1980). Talking about teaching: The contributions of senior faculty to junior faculty. In W.C. Nelsen \& M.E. Siegel (Eds.), Effective approaches to faculty development (pp. 43-48). Washington, DC: Association of American Colleges.

Hodgkinson, H.L. (1983). Guess who's coming to college: A demographic portrait of students in the 1990's. Academe, 69(2), 13-20.

Hoyt, D.P., \& Howard, G.S. (1978). The evaluation of faculty development programs. Research in Higher Education, 8, 25-38.

Jacobson, R. (1985, December 16). New Carnegie data show faculty uneasy about the state of academe and their own careers. Chronicle of Higher Education, pp. 1, 24. 
Joyce, B., \& Showers, B. (1983). Power in staff development through research on training. Alexandria, VA: Association for Supervision of Curriculum Development.

Knowles, M.S. (1984). Andragogy in action. San Francisco, CA: Jossey-Bass.

Lacey, P.A. (1988). Faculty development and the future of college teaching. In R.E. Young and K.E. Eble (Eds.), College teaching and learning: Preparing for new commitments. San Francisco, CA: Jossey-Bass.

Levinson, D.J. (1978). The seasons of a man's life. New York: Knopf.

Levinson-Rose, J., \& Menges, R.J. (1981). Improving college teaching: A critical review of research. Review of Educational Research, 51, 403-434.

McKeachie, W.J., et al. (1986). Teaching and learning in the college classroom: A review of the research literature. Ann Arbor, MI: National Center for Research in Postsecondary Teaching and Learning.

Menges, R.J., \& Brinko, K.T. (1986). Effects of student evaluation feedback: A meta-analysis of higher education research. Paper presented at the annual meeting of the American Educational Research Association, San Francisco, CA.

Near, J.P., \& Sorcinelli, M.D. (1986). Work and life away from work: Predictions of faculty satisfaction. Research in Higher Education, 25(4), 377-394.

Newman Unit's Report on Graduate Education. (1973). Reprinted in the Chronicle of Higher Education, March 12, 1973, pp. 12-27.

Rice, R.E. (1983). Being professional academically. In D.T. Bedsole (Ed.), Critical aspects of faculty development programs. Sherman, TX: Center for Program and Institutional Renewal, Austin College.

Schultz, D.P., \& Schultz, S.E. (1986). Psychology and industry today. New York: Macmillan.

Schuster, J.H., \& Bowen, H.R. (1985). The faculty at risk. Change, September/October.

Siegel, M.E. (1980). Empirical findings on faculty development programs. In W.C. Nelsen \& M.E. Siegel (Eds.), Effective approaches to faculty development (pp. 131-144). Washington, DC: Association of American Colleges.

Sorcinelli, M.D. (1988). Satisfactions and concerns of new university teachers. In J. Kurfiss, L. Hilsen, S. Kahn, M.D. Sorcinelli, and R.G. Tiberius (Eds.), To Improve the Academy, 7, 121-133.

Spelle, H. (1987, June 24). The Chronicle of Higher Education, p. 3.

Stevens, J.J., \& Aleamoni, L.M. (1985). The use of evaluative feedback for instructional improvement: A longitudinal perspective. Instructional Science, 13, 285-304.

Turner, J.L., \& Boice, R. (April 1987). A longitudinal study of faculty careers. Paper presented at the annual meeting of the Western Psychological Association, Long Beach, CA.

Turner, J.L., \& Boice, R. (1987). Starting at the beginning: The concerns and needs of new faculty. In J. Kurfiss, L. Hilsen, L. Mortensen, and E. Wadsworth (Eds.), To Improve the Academy, 6, 41-47. 
Wilson, R.C. (1986). Improving faculty teaching: Effective use of student evaluations and consultants. Joumal of Higher Education, 57(2), 196-211.

Wlodkowski, R.J. (1985). Enhancing adult motivation to learn. San Francisco, CA: JosseyBass. 